\title{
Analysis of Toxicants by Gas Chromatography
}

\author{
Sukesh Narayan Sinha ${ }^{1,{ }^{*}}$ and V. K. Bhatnagar ${ }^{2}$ \\ ${ }^{1}$ National Institute of Nutrition (ICMR), \\ Jamia-Osmania, P.O-Hyderabad, \\ ${ }_{2}^{2}$ rincipal and Dean, Subharti Institute of Technology \& Engineering, \\ Swami Vivekanand Subharti University, Meerut, \\ India
}

\section{Introduction}

Chromatography is an analytical technique which has been used for isolation, purification and separation of organic and inorganic compounds including qualitative and quantitative estimation of compounds. Basically, there are two types of chromatography. One is liquid chromatography and other is Gas chromatography. The chromatography was discovered in 1906 and gas chromatography was developed by Tshett in 1950s. Generally, in GC the mobile phases are gases such as helium $(\mathrm{He})$, or Nitrogen $\left(\mathrm{N}_{2}\right)$. GC depends upon temperature programming and boiling point of the compounds. The volatile organic compounds (VOCs), poly-aromatic hydrocarbon and pesticides have been analysed by gas chromatography-mass spectrometric technique. In this chapter, we present a review of existing analytical methodology for the environmental and biological monitoring of exposure to toxicants. In an effort to provide a more concise exploration of existing toxicants bio-monitoring methodology that is relevant today. In addition, as much of the toxicants analysis work involving effective dose measurements is its infancy (adduct measurements) or do not provide sensitive indicators of exposure, All these methods are in use but some form of chromatography, but the detection systems range from simple UV absorbance detection to sophisticated mass spectrometric analyses. These methods possess limits of detection (LODs) that span a wide range; some are suitable for only occupational or forensic applications while those with LODs near or lower than the low- $\mu$ g/ 1 are useful for detecting incidental environmental exposures. In addition, these methods have been used to measure toxicants and/or their metabolites in a variety of matrices including urine, serum, breast milk, saliva, and post-partum meconium.

\section{Gas chromatography equipped with different detectors for analysis of Arial pollutants}

Generally, five types of detectors are coupled with GC (GC-ECD, GC-NPD, GC-FID, GCPID and GC-MS). The analysis of compounds on GC depends upon nature of compound,

* Corresponding Author 
physical and chemical properties of compound. Gas chromatography coupled with electron capture detector (GC-ECD) is used for qualitative as well as quantitative estimation of organochlorine compounds especially organochlorine pesticides. Gas chromatography coupled with nitrogen phosphorous detector (GC-NPD) is used for quantification of nitrogen and phosphorous containing compounds, especially organophosphate compounds. Gas chromatography coupled with flame ionization detector (GC-FID) is used for quantification of volatile organic compounds. Gas chromatography mass spectrometer (GCMS) is used for quantitative as well as qualitative estimation of non-polar compounds. This technique is very useful for structural confirmation as well as molecular weight determination of compounds. Now, mass spectrometer is used for measurement of molecular weight as well as structural estimation and quantification of compounds. Various types of MS may be used for analysis of protein, peptide, mapping of oligonucleotides, pesticides and air pollutants. MS is also used in industrial as well as pharmaceutical application in drug discovery, poly-aromatic hydrocarbons, poly-chlorinated biphenyl, clinical screening, haemoglobin analysis and drug testing). GC-MS is now a well established routine technique where the MS is viewed as another detector and used for analysis of air samples. GC-MS (eg. High resolution GC-MS (Electron impact (EI), chemical ionization (CI) and negative chemical ionization (NCI) (Ballschmiter et al., 1992; Fischer et al., 1992) techniques were used for the determination of relevant environment parameters (eg. PO, $\mathrm{SH}_{2} \mathrm{O}, \mathrm{KOW}$ ) in the mixture of organic compound. This technique was also used to study the chemistry of incomplete combustion and high temperature pyrolisis. The emission from the technical burning process, including the organic emissions of automobile and their occurrence in environmental samples were studied for the groups of polychlorinated, dibenzofuran, biphenyls, diphenyl ethers, chlorophenols and microbial degradation of polychlorinated pesticides and arenes like the dibenzo-p-dioxins, dibenzofurans and naphthalines. A combined GC-MS technique is used in USA for the Qualitative and quantitative analysis of methyl terbutyl ether (MTBE) and benzene in gasoline (Star et al., 2000; Quach et al., 1998). The GC-MS experiments demonstrate the use of internal standards in the method to improve precision, standard deviation, and ion extraction/monitoring for the measurement of specific highly volatile organic compounds in air samples. The thermally desorbed compounds were analysed by GC/FID (flame ionization detector)/MS utilising a GC oven program ranging from $2^{\circ} \mathrm{C}$ (to prevent column plugging by ice) to $160^{\circ} \mathrm{C}$ and separation on a $30 \mathrm{~m} \times 0.32 \mathrm{~mm}$ DB5-MS capillary column. VOCs are identified on the basis of retention time and mass spectral search, where as quantification is based on FID response which should be calibrated weekly with VOC standards (Hodgson et al., 1989; Reidel,1996). The FID detector is more sensitive than MS detector for analysis of VOC's. Structural characterization of PAC by combined GC-MS and GC-FTIR provides unambiguous identification of the isomers in iomex samples.

GC-MS was used to quantify triphenyl hydroquinol THP (Abdulrahman (2001) in environmental samples. Analysis of these data shows that there is no statistical difference between TPH values quantified with GC-MS and those derived from conventional TPH methods with GC/FID. Further, the GC-MS technique used in the study is readily adaptable to most environmental laboratories for analysis of volatile and semi-volatile compounds (EPA analysis ie 8260 and 8270 method respectively, EPA 845 (Robert, (1993). The implications of these results are 1) additional information (e.g. PAH) is often required when 
conducting a risk based assessment which can be derived from pre-existing site assessment data, thereby decreasing the cost and time required to obtain the additional samples and analytical information, and (2) unique TPH distributions can be critically evaluated with mass spectra in order to ascertain the nature and potential source of the compounds present in the TPH mixtures.

A gas chromatography-mass spectroscopic method in electron ionization (EI) mode with MS/MS ion preparation using helium at flow rate $1 \mathrm{ml} \mathrm{min}^{-1}$ as carrier gas on DB-5 capillary column $(30 \mathrm{~m} \times 0.25 \mathrm{~mm}$ i.d. film thickness $0.25 \mu \mathrm{m})$ has been developed for the determination of benzene in indoor air. The detection limit for benzene was $0.002 \mu \mathrm{g} \mathrm{ml}^{-1}$ with S/N: 4 (S: 66, N: 14). The benzene concentration for cooks during cooking time in indoor kitchen using dung fuel was $114.1 \mu^{-3} \mathrm{gm}^{-3}$ while it was $6.6 \mathrm{\mu gm}^{-3}$ for open type kitchen. The benzene concentration was significantly higher $(p<0.01)$ in indoor kitchen with

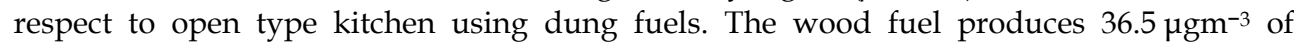
benzene in indoor kitchen. The concentration of benzene in indoor kitchen using wood fuel was significantly $(p<0.01)$ lower in comparison to dung fuel. This method may be helpful for environmental analytical chemist dealing with GC-MS in confirmation and quantification of benzene in environmental samples with health risk exposure assessment (Sinha et al., 2005).

The benzene and toluene was quantified using the GC-MS/ MS technique from indoor air. The geometrical mean (GM) of benzene exposure for cooks during cooking hours in an indoor kitchen using mixed fuel was $75.3 \mu \mathrm{g} / \mathrm{m}^{3}$ (with partition) and $63.206 \mu \mathrm{g} / \mathrm{m}^{3}$ (without partition), while the exposure was $1.7 \mu \mathrm{g} / \mathrm{m}^{3}$ for open type. The benzene exposure was significantly higher $(p<0.05)$ in an indoor kitchen with respect to open type using mixed fuels. Concentration of benzene $\left(114.1 \mu \mathrm{g} / \mathrm{m}^{3}\right)$ for cooks in an indoor kitchen with partition using dung fuel was significantly higher in comparison to open type kitchen. (Sinha et al., 2005). The toxic compounds are toluene, xylene, ethylbenzene, 2-4dimethyl heptanes ,cyclohexane propanol, 1-(methyl ethyl) cyclohexane, propyl benzene, 1-ethyl-3-methyl benzene, heptyl cyclohexane, 1-methyl-3propyl benzene, diethyl benzene, 4-ethyl octane, naphthalene and 3-methyl decane were present in thinner. All these compounds were confirmed using retention time parameter, molecular ion peak and other characteristic peak using National Institute of Science Technology (NIST) library search. The percentage composition of thinner has been also explained (Sinha and Zadi 2008). A GC-MS method is also very useful for measurement of main urinary metabolites of benzene, namely phenol, catechol,hydroquinone, 1,2,4-trihydroxybenzene, $t$,t-muconic acid and S-phenylmercapturic acid. Measurement of urinary benzene was performed via headspace solid phase microextraction of $0.5 \mathrm{~mL}$ of urine specimens followed by GC-MS. A number of methods including GC-FID and GC-MS are available for analysis of benzene from ambient environment but the more sensitive procedure of Pre-concentration on charcoal followed by GC-MS analysis is preferred. GC-MS technique being used for the qualitative and quantitative analysis for methyl tertiary butyl ether (MTBE) and benzene in gasoline. In this method, the internal standard was used to improve precision, standard deviation and ion extraction/ monitoring for the measurement of specific highly volatile organic compounds in air pollution samples (Carmichael et al., 1990). A carbotrap tube $(2 \mathrm{~mm})$ was used to determine volatile organic compounds in ambient air. Such compounds were desorbed and thermally analyzed with GC-MS With the use of GC-MS technique about 54 toxic 
hydrocarbons were quantified in the ambient air of Tehran. Polyurethane foam (PUF) cartridge samples were analyzed for dioxins and furans as per EPA test method TO-9 (Keen and Doug project No 46310001131). This gas chromatography high resolution mass spectrometric (GC-HRMS) method was also used for the analysis of poly chlorinated dibenzofurans in ambient air.

The gas chromatography-electron ionization with single ion monitoring (GC-EI/SIM), gas chromatography-negative chemical ionization with single ion monitoring (GCNCI/SIM), and gas chromatography-negative chemical ionization with single reaction monitoring (GC$\mathrm{NCI} / \mathrm{SRM}$ ) method was developed for the determination of pesticides in air sample extracts at concentrations $<100-\mu \mathrm{gL}^{-1}$. In general, GC-NCI/SIM provided the lowest method detection limits (MDLs commonly 2.5-10 $\mu \mathrm{gL}^{-1}$ ), while GC-NCI/SRM was used for confirmation of parathion-ethyl, tokuthion, carbofenothion. But, as per the reported method GC-EI/ SRM at concentration $<100-\mu \mathrm{gL}^{-1}$ was not suitable for most pesticides. GC-EI/SIM was more prone to interference issues than negative chemical ionization (NCI) methods, but of fixed good sensitivity (MDLs 1-10 $\mu \mathrm{gL}^{-1}$ ) for pesticides with poor NCI response (organophosphates (Ops): sulfotep, phorate, aspon, ethion, and OCs: alachlor,aldrin, perthane, and DDE, DDD, DDT) (Martinez et al., 2004).

\section{Chromatography equipped with different detector for analysis of pesticides in food samples}

GC-MS/MS method was used for the analysis of organochlorine pesticides (OCs) residues $(\mathrm{a}-\mathrm{HCH}, \quad \beta-\mathrm{HCH}, \quad \gamma-\mathrm{HCH}, \quad \delta-\mathrm{HCH}, \mathrm{p}, \mathrm{p}-\mathrm{DDE}, \mathrm{p}, \mathrm{p}-\mathrm{DDD}, \mathrm{p}, \mathrm{p}-\mathrm{DDT}$, a-endosulfan, $\beta$ endosulfan, and endosulfan sulphate) in carbonated drinks (Miller and Miline 2008). Furthermore, a method was reported (Paya et al., 2007) for the analysis of pesticide residues using a quick, cheap, effective, rugged, and safe (QuEChERS) multi-residue method in combination with gas chromatography and tandem mass spectrometric detection (GCMS/MS). A mixture of 38 pesticides was quantitatively recovered from spiked lemon, raisins, wheat and flour using GC-MS/MS, while 42 pesticides were recovered from oranges, red wine, red grapes, raisins and wheat flour using GC-MS/MS for determination (Paya et al., 2007). Several GC methods have also been developed for pesticide residual analysis in different food (Kumari and Kathpal 2009; Kumari et al., 2006; kumara et al., 2002) commodities (e.g., vegetables, fruits and other products of food).

A sensitive method for the quantification of 11 pesticides in sugar samples to the $\mu$ gkg- 1 level has been developed. These pesticides are often used in an agricultural context. A simple solvent extraction followed by selective analysis using a gas chromatography-mass spectrometric method was used. This method was accurate $(>99 \%)$ as it possesses limits of detection in the 0.1 -ug kg-1 range, and the coefficients of variations are less than $15 \%$ at the low $\mu \mathrm{gkg}^{-1}$ end of the method's linear range. The percent recovery of all the pesticides at the lowest levels of detection ranges from $82 \%$ to $104 \%$. This method was used for the quantification of pesticides in sugar samples collected from different factory outlets from different parts of India. In this study, 27 refined sugar samples were analysed in which one sample showed a detectable level of the chlorpyrifos. This study showed that Indian sugar is free from the commonly-used pesticides at the low $\mu \mathrm{gg}^{-1}$ levels (Sinha et al., 2011). 


\begin{tabular}{|c|c|c|c|c|c|c|c|c|}
\hline Pesticide & Matrices & $\begin{array}{l}\text { Sample } \\
\text { preparation }\end{array}$ & $\begin{array}{l}\text { Instru- } \\
\text { ment used }\end{array}$ & $\begin{array}{l}\text { aLOD } \\
\text { ranged } \\
\left(\mu \mathrm{gkg}^{-1}\right)\end{array}$ & $\begin{array}{l}\text { bLOQ } \\
\text { ranged } \\
\left(\mu \mathrm{gkg}^{-1}\right)\end{array}$ & $\begin{array}{l}\text { \% Recovery } \\
\text { ranged } \\
\text { (\%mean) }\end{array}$ & $\begin{array}{l}\text { cRSD } \\
\text { ranged } \\
(\%)\end{array}$ & $\begin{array}{l}\text { Refe- } \\
\text { rences }\end{array}$ \\
\hline OPs & vegetables & $\begin{array}{l}\text { Solvent } \\
\text { extraction }\end{array}$ & GC-PID & 3 to10 & NR & $\begin{array}{l}75.2 \% \text { to } \\
111.5 \%\end{array}$ & $\begin{array}{l}2.8 \% \\
\text { to } \\
10.4 \% .\end{array}$ & $\begin{array}{l}\mathrm{Li} \\
\text { et al., } \\
2010\end{array}$ \\
\hline OPs & vegetables & $\begin{array}{l}\text { solvent } \\
\text { extraction } \\
\text { with SPE }\end{array}$ & $\begin{array}{l}\text { CEI with } \\
\text { quantum } \\
\text { dot fluore- } \\
\text { scence } \\
\text { detection }\end{array}$ & $\begin{array}{l}50 \text { to } \\
180, \text { and } \\
100- \\
30000\end{array}$ & NR & $88.7-96.1 \%$ & & $\begin{array}{l}\text { Chen et } \\
\text { al., 2010) }\end{array}$ \\
\hline pesticides & $\begin{array}{l}\text { Fruit+ } \\
\text { vegetable }\end{array}$ & QuEChERS & $\begin{array}{l}\text { LC-MS/ } \\
\text { MS }\end{array}$ & NR & NR & $\begin{array}{l}70 \% \text { to } \\
120 \%\end{array}$ & $>20 \%$ & $\begin{array}{l}\text { Camino- } \\
\text { Sánchez } \\
\text { et al., } \\
\text { 2010) }\end{array}$ \\
\hline pesticides & olives & $\begin{array}{l}\text { solid-phase } \\
\text { dispersion } \\
\text { and } \\
\text { QuEChERS }\end{array}$ & $\begin{array}{l}\text { LC-MS/ } \\
\text { MS }\end{array}$ & 10 & NR & $70-120 \%$ & & $\begin{array}{l}\text { Gilbert- } \\
\text { López et } \\
\text { al., } 2010\end{array}$ \\
\hline $\begin{array}{l}\text { Pesticides } \\
\text { (OCs }+ \\
\text { Ops) } \\
\end{array}$ & vegetable & QuEChERS & GC-NPD & 1 to 9 & NR & $\begin{array}{l}70.22 \% \text { to } \\
96.32 \%\end{array}$ & $>15 \%$ & $\begin{array}{l}\text { Srivastav } \\
\text { a et al., } \\
2010 \\
\end{array}$ \\
\hline pesticides & $\begin{array}{l}\text { fruits and } \\
\text { vegetables }\end{array}$ & QuEChERS & $\begin{array}{l}\text { LP-GC/ } \\
\text { TOFMS }\end{array}$ & NR & NR & $70-120 \%$ & $<20 \%$ & $\begin{array}{l}\text { Koesukw } \\
\text { iwat et } \\
\text { al., } 2010\end{array}$ \\
\hline Pesticides & vegetables & NR & GC-MS & NR & NR & NR & NR & $\begin{array}{l}\text { Osman et } \\
\text { al., } 2010\end{array}$ \\
\hline Pesticides & vegetables & QuEChERS & $\begin{array}{l}\text { LC- } \\
\text { MS/MS }\end{array}$ & NR & NR & NR & NR & $\begin{array}{l}\text { Kmellár } \\
\text { et al., } \\
2010 \\
\end{array}$ \\
\hline $\begin{array}{l}\text { Ops and } \\
\text { carba- } \\
\text { mates }\end{array}$ & total diet & QuEChERS & $\begin{array}{l}\text { LC-MS/ } \\
\text { MS }\end{array}$ & NR & 200 & $70-120 \%$ & $<20 \%$ & $\begin{array}{l}\text { Chung et } \\
\text { al., } 2010\end{array}$ \\
\hline pesticides & vegetables & $\begin{array}{l}\text { Liquid } \\
\text { extraction }\end{array}$ & HPLC & $0.5-3.0$ & NR & $77.8-98.2 \%$ & NR & $\begin{array}{l}\text { Lin et al., } \\
2010\end{array}$ \\
\hline pesticides & $\begin{array}{l}\text { Vegetable } \\
+ \text { fruits }\end{array}$ & $\begin{array}{l}\text { Solid phase } \\
\text { extraction }\end{array}$ & $\begin{array}{l}\text { UPLC- } \\
\text { MS/MS }\end{array}$ & $1-2000$ & NR & $70-120 \%$ & NR & $\begin{array}{l}\text { Kamel } \\
\text { et al., } \\
2010\end{array}$ \\
\hline
\end{tabular}

$\mathrm{NR}=$ Not reported

LOD $=$ Limit of detection

LOQ $=$ Limit of quantification

$\mathrm{RSD}=$ Relative standard deviation

Table 1. Different reported methods in food matrices.

The reported method for the analysis of pesticides in food samples is tabulated in Table-1. However, recently, a method has been reported ( $\mathrm{Li} \mathrm{Wu}$, Chen \& Zhang 2010) detailing the 
percentage recoveries, RSD, and LOD in vegetable sample. The reported RSD for all the pesticides used in this study ranged from $2.8 \%$ to $10.4 \%$ and the recovery ranged from $75 \%$ to $11 \%$. The reported LOD in vegetable samples ranged from 3 to $10 \mu \mathrm{gg}^{-1}$ for all pesticides. Also, an LC-MS/MS method has been used for the analysis of pesticides in fruit and vegetable samples (Camino sanchez et al., 2010). In this method, QuEChERS was used for the extraction. The reported mean percentage recoveries mostly ranged between $70 \%$ and $120 \%$, and RSD were generally below $20 \%$ at the lower spiked level. The CEI with quantum dot fluorescence detector was used for analysis of vegetable samples (Chen \& Fung 2010). The reported LOD ranged from 50 to $180 \mu \mathrm{gkg}^{-1}$, while the reported recovery ranged between $88 \%$ and $96 \%$. Additionally, the LC-MS/MS was used by different researcher (Gilbert-Lopez et al., 2010; Kmellar, Abranko, Fodor \& Lehotay 2010; Chun \& Chan 2010) for analysis of pesticides in olives, vegetables and total diet samples. In this method, QuEChERS was used for the extraction. The reported mean percentage recoveries mostly ranged between $70 \%$ and $120 \%$, and RSD were below $20 \%$. The reported LOD was $10 \mu \mathrm{gkg}-1$. The GC-MS method was used for analysis of pesticides in fruits and vegetables samples (Koesukwiwat, Lehotay, Miao \& Lepipatpiboon, 2010; Osman, Al-Humaid, Al-Rehiayani \& Al-Redhalman, 2010). The simultaneous identification and quantification of pesticide residues in fruits, milk and vegetables were reported (Kamel, Qian, Kolbe \& Stafford, 2010). This method was based on solid phase extraction followed by UPLC-MS/MS chromatographic separation and a full-scan mass spectrometric detection. The recovery for all pesticides ranged from $70 \%$ to $120 \%$ with LOD ranged from 1 to $2000 \mu \mathrm{gkg}^{-1}$. The HPLC method was also used for analysis of pesticides in vegetables samples (Lin et al., 2010). In this method liquid extraction was used. In the vegetable samples, the observed recoveries ranged from $77 \%$ to $99 \%$ and LOD ranged from 0.5 to $3 \mu \mathrm{kg}^{-1}$ while GC-NPD was used for analysis of vegetable samples reported mean percentage recoveries mostly ranged between $70 \%$ and $96 \%$, and RSD were generally below 15\% (Srivastava, Trivedi, Srivastava, Lohani \& Srivastava 2010). The LOD values ranged from 1 to $9 \mu \mathrm{gkg}^{-1}$. However it should be noted that HPLC and GC-NPD are not confirmatory techniques.

\section{Gas chromatography equipped with different detector for analysis of pesticides in biological samples}

A sensitive GC-MS method in MS/MS ion preparation was developed for quantitative estimation and qualitative determination of chlorpyrifos in human blood samples. Dissociation energy effects on ion formation of chlorpyrifos and sensitivity of this analytical method was well demonstrated. Chlorpyrifos was extracted using methanol/hexane mixture from $0.2 \mathrm{ml}$ human blood, deactivated with saturated acidic salt solution. The extract was then re-concentrated and analyzed by electron impact (EI) MS/MS gas chromatography-mass spectrometer. The MS/MS spectra of chlorpyrifos ion were recorded on different dissociation energy $(30-100 \mathrm{~V})$ to establish the structural confirmation and to demonstrate the effect of this energy on sensitivity, $S / N$ ratio and detection limit for quantification of chlorpyrifos, which is reported for the first time. At different exciting amplitude (30-100 V), different behaviors of base peak, sensitivity, $S / N$ ratio and detection limit of this method were observed for quantification of chlorpyrifos. The mass spectra recorded at dissociation energy $<70 \mathrm{~V}$, in between $70-80 \mathrm{~V}$ and $>80 \mathrm{~V}$ correspond to the $\mathrm{m} / \mathrm{z}$ $314(100 \%), m / z 286(100 \%)$ and $m / z 258(100 \%)$, respectively. The sensitivity, signal to noise ratio and detection limit of this method increased on $95 \mathrm{~V}$ at $m / z 258$. Therefore, $m / z 258$ 
was used for the quantification of chlorpyrifos. The detection limit for quantification was $0.1 \mathrm{ng} / \mathrm{ml}$ with $S / \mathrm{N}: 2$ in human blood. The linear calibration curve with the correlation coefficient $(r>0.99)$ was obtained. The percentage recoveries from $95.33 \%$ to $107.67 \%$ were observed for chlorpyrifos from human blood. The blood samples were collected at different time intervals. The concentration of chlorpyrifos in Poisoning case was 3300, 3000, 2200, $1000,600,300 \mathrm{ng} / \mathrm{ml}$ on day 1, 3, 6, 8, 10 and 12, respectively. On the 12th day of exposure of chlorpyrifos, $90.9 \%$ reduction in concentration was observed. On day $14^{\text {th }}$, the chlorpyrifos was not detected in the blood of the same subject. Thus, the present study is useful for detection of chlorpyrifos in critical care practices and also provides tremendous selectivity advantages due to matrix elimination in the parent ion isolation step in blood sample analysis for chlorpyrifos (Sinha et al., 2006). The effect of dissociation energy on ion formation and sensitivity of triazofos in blood samples was studied. Six millilitres hexane was used for the extraction of triazofos from $2 \mathrm{~mL}$ serum samples. The extract was reconstituted in $1 \mathrm{~mL}$ hexane and analyzed by GC-MS/MS in electron impact MS/MS mode. The structure, ion formations, nature of base peak and fragmentation schemes were correlated with the different dissociation energies. The new ion was obtained at mass to charge ratio $161(100 \%)$, which was the characteristic ion peak of triazofos. On using different exciting amplitudes, different behaviours of fragmentation schemes were obtained. The effect of dissociation energy on sensitivity of the analyte was also demonstrated. The mass spectra recorded at different exciting amplitudes $<50 \mathrm{~V}$ in between $50-60 \mathrm{~V}$ and $>60 \mathrm{~V}$ correspond to the $\mathrm{m} / \mathrm{z} 161(100 \%), 77$ (100\%) and $119(100 \%)$, respectively. The maximum sensitivity of analyte in blood sample was obtained on using $50 \mathrm{~V}$ dissociation energy. Additionally, the effect of current on sensitivity of the method was also demonstrated. In all conditions, the new characteristic ion at $\mathrm{m} / \mathrm{z} 161$ was obtained and used for quantification of triazofos in blood samples with maximum sensitivity. The limit of detection and quantification was 0.351 and 1.17 ngmL $^{-1}$, respectively, with $99 \%$ accuracy. The observed correlation coefficient was 0.995 . The inter-day percentage recoveries from $83.9 \%$ to $111 \%$ were obtained below 9.38 percentage RSD. This present method gives combined picture of confirmation and quantification of triazofos in critical care practices and also provides tremendous selectivity advantages due to matrix elimination in the parent ion isolation step in blood sample analysis for triazofos in poisoning emergency cases (Sinha 2010). A number of families in a rural area of Jabalpur District (Madhya Pradesh), India, were affected by repeated episodes of convulsive illness over a period of three weeks. The aim of this investigation was to determine the cause of the illness. The investigation included a house-to-house survey, interviews of affected families, discussions with treating physicians, and examination of hospital records. Endosulfan poisoning was suspected as many villagers were using empty pesticide containers for food storage. To confirm this, our team collected blood and food samples, which were transported to the laboratory and analyzed with GC-ECD. Thirty-six persons of all age groups had illness of varying severity over a period of three weeks. In the first week, due to superstitions and lack of treatment, three children died. In the second week, symptomatic treatment of affected persons in a district hospital led to recovery but recurrence of convulsive episodes occurred after the return home. In the third week, 10 people were again hospitalized in a teaching hospital. Investigations carried out in this hospital ruled out infective etiology but no facilities were available for chemical analysis. All persons responded to symptomatic treatment. The presence of endosulfan in blood and food samples was confirmed by GCMS. One of the food items (Laddu) prepared 
from wheat flour was found to contain $676 \mathrm{ppm}$ of a-endosulfan. Contamination of wheat grains or flour with endosulfan and its consumption over a period of time was the most likely cause of repeated episodes of convulsions, but the exact reason for this contamination could not be determined. This report highlights the unsafe disposal of pesticide containers by illiterate farm workers, superstitions leading to delay in treatment, and susceptibility of children to endosulfan (Dewan et al., 2004). Mass spectrometry method has been used with capillary gas chromatography in electron ionization mode to identify the presence of $a, \beta$ and endosulfan sulphate in human serum samples. The fragmentation ions were obtained due to ring cleavages, rearrangement and remote charge process. Solvent extraction procedure was used for isolation of compounds from serum sample. A detection limit as low as $100 \mathrm{ppb}$ for $\alpha, \beta$ and endosulfan sulphate could be easily achieved for confirmation. For endosulfan and endosulfan sulphate the $\mathrm{m} / \mathrm{z}$ values were obtained at intervals of $\mathrm{M}^{+2}$. The $\mathrm{m} / \mathrm{z}$ values of $\alpha, \beta$ endosulfan are identical but they differed in retention time (Sinha et al., 2004). Therefore, the spectra reported might serve as reference spectra for identification of different type of organo-chlorine pesticide in human serum samples. The GC-MS has been employed to quantitatively detect at low ppb levels of $a$ and $\beta$ endosulfan in human serum, urine and liver but this failed to separate $\alpha, \beta$-isomers. GC equipped with a mass detector was used to measure the levels of endosulfan in human blood at ppb level.

Although some OC pesticide metabolites are monitored in urine, they are most commonly measured as the intact pesticide and/or its metabolite in whole blood, serum, plasma, or other lipid-rich matrices. These methods and the specific pesticides measured are outlined in Table 2. Although some pesticide metabolites are monitored in urine, they are most commonly measured as the intact pesticide and/or its metabolite in, whole blood, serum, plasma, or other lipid-rich matrices. Typically, serum or plasma is extracted using a liquid partitioning or solid-phase extraction (SPE) and the extract is analyzed using capillary gas chromatography (GC) with electron-capture detection (ECD) (Table-2). These methods are reliable and use affordable instrumentation. However, GC-ECD analyses have a higher potential for detecting interfering components than do more selective analysis techniques. Other methods for analysis of serum extracts include mass selective detection (MSD aka MS) [Table-2] and high-resolution mass spectrometry with isotope dilution quantification. These analyses are typically more selective and sensitive than GC-ECD analyses; however, the high cost of instrumentation and isotopically labeled standards and the complex operation and maintenance of these instruments often preclude their routine use in most laboratories.

Typically, serum or plasma is extracted using a liquid partitioning or solid-phase extraction (SPE) and the extract is analyzed using capillary gas chromatography (GC) with electroncapture detection (ECD) (Table-2). A sensitive and accurate analytical method was developed for quantifying 29 contemporary pesticides in human serum or plasma. These pesticides include organophosphates, carbamates, chloroacetanilides, and synthetic pyrethroids among others and include pesticides used in agricultural and residential settings. This method employs a simple solid-phase extraction followed by a highly selective analysis using isotope dilution gas chromatography-high-resolution mass spectrometry. This method is very accurate, has limits of detection in the low $\mathrm{pg} / \mathrm{g}$ range and coefficients of variation of typically less than $20 \%$ at the low pg/g end of the method linear range (Barr et al., 2002). 


\begin{tabular}{|c|c|c|c|c|c|c|c|c|}
\hline Method & Analytesa & Matrix & Extraction & $\begin{array}{l}\text { Analyti- } \\
\text { cal system }\end{array}$ & I.S. type & $\begin{array}{l}\text { Recoverye } \\
(\%)\end{array}$ & $\begin{array}{l}\text { LOD } \\
(\mu \mathrm{g} / \mathrm{g})\end{array}$ & $\begin{array}{l}\text { RSD } \\
(\%)\end{array}$ \\
\hline \begin{tabular}{|l}
$\begin{array}{l}\text { Frenzel, } \\
2000\end{array}$ \\
\end{tabular} & 15 & $\begin{array}{l}\text { Whole } \\
\text { blood }\end{array}$ & $\begin{array}{l}\text { Kieselguhr } \\
\text { SPE }\end{array}$ & GC-MS & None & 97 & $30-40$ & 7 \\
\hline \begin{tabular}{|l} 
Rohrig, \\
2000
\end{tabular} & $1-6$ & $\begin{array}{l}\text { Breast } \\
\text { milk }\end{array}$ & SPME & GC-ECD & None & $\mathrm{b}$ & Low & $b$ \\
\hline $\begin{array}{l}\text { Ward, } \\
2000\end{array}$ & $1-10$ & $\begin{array}{l}\text { Serum, } \\
\text { breast }\end{array}$ & SPE & \begin{tabular}{|l} 
GC- \\
HRMS
\end{tabular} & \begin{tabular}{|l|} 
Isotope \\
dilution
\end{tabular} & $60-80$ & $\begin{array}{l}0.07- \\
0.26\end{array}$ & $<20$ \\
\hline $\begin{array}{l}\text { Najam, } \\
1999\end{array}$ & $\begin{array}{l}1-3,5-12 \\
13,17-18\end{array}$ & Serum & $\begin{array}{l}\text { Solvent } \\
\text { extraction, } \\
\text { Silica / } \\
\text { Florosil } \\
\text { cleanup } \\
\end{array}$ & GC-ECD & $\begin{array}{l}\text { Sur- } \\
\text { rogates }\end{array}$ & $39-126$ & $\begin{array}{l}0.15- \\
0.5\end{array}$ & $7-32$ \\
\hline $\begin{array}{l}\text { Pauwels, } \\
1999\end{array}$ & $\mathrm{f}$ & Serum & $\begin{array}{l}\mathrm{C}_{18} \mathrm{SPE}, \\
\text { acid } \\
\text { wash }\end{array}$ & GC-MS & $\begin{array}{l}{ }^{13} C_{12} \\
\text { PCB } 149\end{array}$ & $48-140$ & Low & $\mathrm{b}$ \\
\hline Lino, 1998 & $\mathrm{f}$ & Serum & Florisil SPE & GC-ECD & $\mathrm{f}$ & $>84$ & $\begin{array}{l}1-37 \\
\mu \mathrm{g} / 1\end{array}$ & $<! 9$ \\
\hline Luo, 1997 & 1,2 & Serum & n-Hexane & GC-ECD & $b$ & 93-106 & $b$ & $\mathrm{~b}$ \\
\hline $\begin{array}{l}\text { Walisze- } \\
\text { wski, } 1982\end{array}$ & $1,2,4,6$ & Adipose & $\begin{array}{l}\text { Light } \\
\text { petroleum, } \\
\text { acid wash }\end{array}$ & GC-ECD & $b$ & 91-99 & $\begin{array}{l}0.01 \\
\mu \mathrm{g} / \mathrm{kg}\end{array}$ & $<10$ \\
\hline \begin{tabular}{|l} 
Brock, \\
1996
\end{tabular} & $1-11$ & Serum & $\begin{array}{l}\mathrm{C}_{18} \mathrm{SPE}, \\
\text { Florosil }\end{array}$ & GC-ECD & $\begin{array}{l}\text { Sur- } \\
\text { rogates }\end{array}$ & $63-80$ & $\begin{array}{l}0.08- \\
0.66 \\
\mu \mathrm{g} / 1 \\
\end{array}$ & $\begin{array}{l}0.7- \\
5.9 c\end{array}$ \\
\hline $\begin{array}{l}\text { Noren, } \\
1996\end{array}$ & $\begin{array}{l}\text { MeSO - } \\
\text { DDE }\end{array}$ & $\begin{array}{l}\text { Breast } \\
\text { milk }\end{array}$ & \begin{tabular}{|l|} 
Liquid-gel \\
partitioning, \\
absorption/ \\
gel \\
permeation \\
chroma- \\
tography \\
\end{tabular} & $\begin{array}{l}\text { GC- } \\
\text { HRMS }\end{array}$ & $\begin{array}{l}\text { Sur- } \\
\text { rogates }\end{array}$ & $80-97$ & $\begin{array}{l}0.01- \\
0.05 \\
\text { ng/g } \\
\text { lipid }\end{array}$ & $4-14$ \\
\hline Gill, 1996 & $\begin{array}{l}1-9,11-13 \\
15+\text { others }\end{array}$ & Serum & $\begin{array}{l}\text { Solvent } \\
\text { extraction } \\
\text { /SPE } \\
\end{array}$ & GC-MS & $\begin{array}{l}\text { Sur- } \\
\text { rogates }\end{array}$ & $60-110$ & $b$ & $\mathrm{~b}$ \\
\hline \begin{tabular}{|l|} 
Guardino, \\
1996 \\
\end{tabular} & 1,2 & Blood & $\mathrm{C}_{18} \mathrm{SPE}$ & GC-ECD; & None & $\mathrm{b}$ & $b$ & $\mathrm{~b}$ \\
\hline $\begin{array}{l}\text { Minelli, } \\
1996\end{array}$ & $1,2,4-6$ & Serum & $\begin{array}{l}\text { Serum-silica } \\
\text { suspension, } \\
\text { hexane/ } \\
\text { acetone, } \\
\text { alumina } \\
\text { cleanup }\end{array}$ & GC-ECD & $b$ & $80-99$ & $\begin{array}{l}<1 \\
\mathrm{mg} / \mathrm{l}\end{array}$ & $<15$ \\
\hline $\begin{array}{l}\text { Gallelli, } \\
1995\end{array}$ & $\mathrm{f}$ & $\begin{array}{l}\text { Adipose } \\
\text { liver }\end{array}$ & \begin{tabular}{|l} 
Light \\
petroleum, \\
Florosil \\
\end{tabular} & GC-ECD & $\mathrm{f}$ & $\mathrm{f}$ & $\mathrm{f}$ & $\mathrm{f}$ \\
\hline
\end{tabular}




\begin{tabular}{|c|c|c|c|c|c|c|c|c|}
\hline Method & Analytes ${ }^{a}$ & Matrix & Extraction & \begin{tabular}{|l|} 
Analyti- \\
cal system
\end{tabular} & I.S. type & $\begin{array}{l}\text { Recoverye } \\
(\%)\end{array}$ & \begin{tabular}{|l|} 
LOD \\
$(\mu \mathrm{g} / \mathrm{g})$
\end{tabular} & $\begin{array}{l}\text { RSD } \\
(\%)\end{array}$ \\
\hline $\begin{array}{l}\text { Prapa- } \\
\text { montol, } \\
1991\end{array}$ & $\begin{array}{l}1-2,4-7 \\
10-13\end{array}$ & Milk & $\begin{array}{l}\text { Ethyl acetate } \\
\text { / acetone } \\
\text { / methanol, } \\
\mathrm{C}_{18} \mathrm{SPE}\end{array}$ & GC-ECD & \begin{tabular}{|l|} 
Sur- \\
rogates
\end{tabular} & $90-110$ & \begin{tabular}{|l|}
$0.5-2.5$ \\
$\mu \mathrm{g} / 1$
\end{tabular} & $\leq 16$ \\
\hline \begin{tabular}{|l|} 
Burse, \\
1990 \\
\end{tabular} & $\begin{array}{l}1-3,5-10, \\
12\end{array}$ & Serum & $\begin{array}{l}\begin{array}{l}\text { Hexane/ } \\
\text { ether, Florosil }\end{array} \\
\end{array}$ & GC-ECD & \begin{tabular}{|l|} 
Sur- \\
rogates
\end{tabular} & $48-122$ & $\begin{array}{l}<1 \mu \mathrm{g} / \\
1\end{array}$ & $7-23$ \\
\hline \begin{tabular}{|l|} 
Saady, \\
1990 \\
\end{tabular} & $\begin{array}{l}-2,4,6,7- \\
10\end{array}$ & Serum & $\mathrm{C}_{18} \mathrm{SPE}$ & GC-ECD & \begin{tabular}{|l|} 
Sur- \\
rogate
\end{tabular} & $70-75$ & \begin{tabular}{|l|}
$0.1-0.7$ \\
$\mu \mathrm{g} / 1$
\end{tabular} & $4-25$ \\
\hline Liao, 1988 & $1-5,11$ & Adipose & \begin{tabular}{|l} 
solvent, \\
Florosil
\end{tabular} & GC-MS & $\begin{array}{l}\text { Sur- } \\
\text { rogat }\end{array}$ & $72-120$ & b & $\mathrm{b}$ \\
\hline \begin{tabular}{|l|} 
Mardones \\
1999
\end{tabular} & 14 & Urine & $\begin{array}{l}\text { Acid } \\
\text { hydrolysis, } \\
\text { on-line } \\
\text { cleanup SFE }\end{array}$ & $\begin{array}{l}\text { MEKC- } \\
\text { UV }\end{array}$ & $b$ & $58-103$ & $\begin{array}{l}1-12 \\
\mu g / 1\end{array}$ & $3-7$ \\
\hline \begin{tabular}{|l} 
LeBel, \\
1983
\end{tabular} & $\mathrm{f}$ & $\mathrm{f}$ & $\begin{array}{l}\text { Acetone/ } \\
\text { hexane, gel } \\
\text { permeation, } \\
\text { dichloro- } \\
\text { methane/ } \\
\text { cyclohexane }\end{array}$ & GC-ECD & B & $>80$ & $b$ & $\mathrm{~b}$ \\
\hline \begin{tabular}{|l} 
Bristol, \\
1982 \\
\end{tabular} & $3,5,7-9,11$ & $\mathrm{f}$ & $\mathrm{f}$ & $\begin{array}{l}\text { GC- } \\
\text { ECD }^{d} \\
\end{array}$ & \begin{tabular}{|l|}
$\begin{array}{l}\text { Sur- } \\
\text { rogates }\end{array}$ \\
\end{tabular} & $35-99$ & $\begin{array}{l}\text { Low } \\
\mu \mathrm{g} / 1 \\
\end{array}$ & $3-20$ \\
\hline \begin{tabular}{|l} 
Tessari, \\
1980
\end{tabular} & $\begin{array}{l}1-3,7-10 \\
13\end{array}$ & $\begin{array}{l}\text { Breast } \\
\text { milk }\end{array}$ & $\begin{array}{l}\text { ACN/ } \\
\text { hexane, } \\
\text { Florosil }\end{array}$ & GC-ECD & $b$ & $68-90$ & $\begin{array}{l}0.5-30 \\
\mu \mathrm{g} / 1\end{array}$ & $\mathrm{~b}$ \\
\hline \begin{tabular}{|l|} 
Strassman \\
1977
\end{tabular} & $1-13$ & $\begin{array}{l}\text { Breast } \\
\text { milk }\end{array}$ & \begin{tabular}{|l} 
Solvent, \\
Florosil
\end{tabular} & $\begin{array}{l}\text { GC- } \\
\text { ECDd }\end{array}$ & $b$ & $\mathrm{~b}$ & $\begin{array}{l}10-100 \\
\mu \mathrm{g} / 1\end{array}$ & $\mathrm{~b}$ \\
\hline $\begin{array}{l}\text { Martinez, } \\
1998\end{array}$ & 15 & Urine & SPE & \begin{tabular}{|l|} 
GC-MS- \\
MS
\end{tabular} & Dieldrin & $>89$ & $\begin{array}{l}0.006- \\
0.018 \\
\mu g / 1\end{array}$ & $9-13$ \\
\hline Nigg, 1991 & 17 & Urine & $\begin{array}{l}\text { Oxidation, } \\
\text { solvent }\end{array}$ & \begin{tabular}{|l|} 
GC \\
(detector \\
not noted) \\
\end{tabular} & None & $\mathrm{b}$ & 1 & $\mathrm{~b}$ \\
\hline $\begin{array}{l}\text { Angerer, } \\
1981\end{array}$ & 14 & Urine & \begin{tabular}{|l|} 
Acid \\
hydrolysis, \\
derivatization \\
\end{tabular} & GC-ECD & $\mathrm{f}$ & 87-119 & $\begin{array}{l}5-20 \\
\mu g / 1\end{array}$ & $4-10$ \\
\hline $\begin{array}{l}\text { Holler, } \\
1989\end{array}$ & 14 & Urine & $\begin{array}{l}\text { Acid } \\
\text { hydrolysis, } \\
\text { derivatization }\end{array}$ & $\begin{array}{l}\text { GC-MS- } \\
\text { MS }\end{array}$ & \begin{tabular}{|l|} 
Isotope \\
analogu- \\
es/sur- \\
rogates
\end{tabular} & $>50$ & 1 & c \\
\hline Hill, 1995 & 14 & Urine & \begin{tabular}{l|} 
Enzyme \\
hydrolysis, \\
chlorobutane \\
/ ether; \\
derivatization \\
\end{tabular} & $\begin{array}{l}\text { GC-MS- } \\
\text { MS }\end{array}$ & \begin{tabular}{|l|} 
Stable \\
isotope \\
ana- \\
logues
\end{tabular} & $\mathrm{b}$ & $\begin{array}{l}1-2 \\
\mu g / 1\end{array}$ & $\begin{array}{l}21- \\
24\end{array}$ \\
\hline
\end{tabular}




\begin{tabular}{|c|c|c|c|c|c|c|c|c|}
\hline Method & Analytes ${ }^{a}$ & Matrix & Extraction & \begin{tabular}{|l|} 
Analyti- \\
cal system
\end{tabular} & I.S. type & $\begin{array}{l}\text { Recoverye } \\
(\%)\end{array}$ & \begin{tabular}{|l|} 
LOD \\
$(\mu \mathrm{g} / \mathrm{g})$
\end{tabular} & $\begin{array}{l}\text { RSD } \\
(\%)\end{array}$ \\
\hline $\begin{array}{l}\text { Heleni } \\
\text { Tsoukali } \\
\text { et al., } 2005\end{array}$ & $\begin{array}{l}\text { malathion, } \\
\text { parathion, } \\
\text { methyl } \\
\text { parathion } \\
\text { and } \\
\text { diazinon }\end{array}$ & $\begin{array}{l}\text { bio- } \\
\text { logical } \\
\text { samples }\end{array}$ & SPME & GC-NPD & $\begin{array}{l}\text { Fenitro- } \\
\text { thion }\end{array}$ & $\mathrm{b}$ & $\begin{array}{l}2 \text { to } 55 \\
\mathrm{ng} / \mathrm{ml}\end{array}$ & b \\
\hline \begin{tabular}{|l} 
Zlatković \\
M, et al., \\
2010
\end{tabular} & \begin{tabular}{|l|} 
dimethoate, \\
diazinon, \\
malathion \\
and \\
malaoxon \\
\end{tabular} & $\begin{array}{l}\text { bio- } \\
\text { logical } \\
\text { samples }\end{array}$ & $\begin{array}{l}\text { solid-phase } \\
\text { extraction }\end{array}$ & LC-MS & $b$ & $90-99$ & $\begin{array}{l}0.007- \\
0.07 \\
\mathrm{mg} / 1\end{array}$ & $b$ \\
\hline $\begin{array}{l}\text { John H et } \\
\text { al., } 2010\end{array}$ & dimethoate & $\begin{array}{l}\text { bio- } \\
\text { logical } \\
\text { samples }\end{array}$ & $\begin{array}{l}\text { Deproteini- } \\
\text { zation by } \\
\text { precipitation } \\
\text { and } \\
\text { extensive } \\
\text { dilution }\end{array}$ & $\begin{array}{l}\text { LC- } \\
\text { MS/MS }\end{array}$ & $b$ & $90-115$ & $\begin{array}{l}0.12- \\
0.24 \\
\mu g / 1\end{array}$ & $5-14$ \\
\hline \begin{tabular}{|l|} 
Paula \\
Proença et \\
al., 2005 \\
\end{tabular} & $\begin{array}{l}\text { imi- } \\
\text { dacloprid }\end{array}$ & $\begin{array}{l}\text { bio- } \\
\text { logical } \\
\text { samples }\end{array}$ & $\mathrm{b}$ & LC-MS & $b$ & 86 & $\begin{array}{l}0.002 \mu \\
\mathrm{g} / \mathrm{mL}\end{array}$ & 5.9 \\
\hline \begin{tabular}{|l|} 
Gallardo \\
et al., 2006
\end{tabular} & dimethoate & $\begin{array}{l}\text { bio- } \\
\text { logical } \\
\text { samples }\end{array}$ & SPME & GC-MS & ethion & $\begin{array}{l}1.24 \text { and } \\
0.50 \% \text {. }\end{array}$ & $\begin{array}{l}50-500 \\
\mathrm{ng} / \mathrm{ml}\end{array}$ & \\
\hline $\mid \begin{array}{l}\text { Saito et } \\
\text { al., } 2008\end{array}$ & & $\begin{array}{l}\text { bio- } \\
\text { logical } \\
\text { samples }\end{array}$ & SPME & $\begin{array}{l}\text { HS-GC- } \\
\text { MS }\end{array}$ & b & b & $\left|\begin{array}{l}0.25 \\
\mu \mathrm{g} / \mathrm{mL}\end{array}\right|$ & 12.6 \\
\hline $\begin{array}{l}\text { Bichon et } \\
\text { al } 2008\end{array}$ & Fipronil & $\begin{array}{l}\text { bio- } \\
\text { logical } \\
\text { samples }\end{array}$ & SPE & GC-MS & b & b & $\begin{array}{l}0.05- \\
0.73 \\
\mathrm{pg} / \mathrm{ml}\end{array}$ & b \\
\hline $\begin{array}{l}\text { Zhou et } \\
\text { al., } 2007\end{array}$ & $\begin{array}{l}\text { pentachlor } \\
\text { ophenol }\end{array}$ & $\begin{array}{l}\text { bio- } \\
\text { logical } \\
\text { samples }\end{array}$ & HS-SPME & GC-MS & $b$ & $\mathrm{~b}$ & $\begin{array}{l}0.02 \\
\mathrm{ng} / \mathrm{ml}\end{array}$ & 12.6 \\
\hline
\end{tabular}

I.S. = Internal standard; $\mathrm{LOD}=$ limit of detection; $\mathrm{RSD}=$ relative standard deviation; $\mathrm{SPME}=$ solidphase micro-extraction; SPE = solid-phase extraction; $\mathrm{SFE}=$ supercritical fluid extraction; $\mathrm{GC}-\mathrm{ECD}=$ gas chromatography electron capture detection; GC-MS= gas chromatography-mass spectrometry, GC-HRMS=gas chromatography-high-resolution mass spectrometry;. a $1=p, p$-DDT; $2=p, p$-DDE; $3=$ hexachlorobenzene; $4=$ a-hexachlorocyclohexane; $5=$ b-hexachlorocyclohexane; $6=$ g-hexachlorocyclohexane; $7=$ heptachlor epoxide; $8=$ oxychlordane; $9=$ trans-nonachlor; $10=$ dieldrin; $11=$ aldrin; $12=$ endrin; $13=$ mirex; $14=$ lindane and/or metabolites (chlorinated phenols); $15=$ endosulfan and/or metabolites; $16=$ methylsulfonyl-DDE; $17=o, p$-DDT; $18=c i s$-nonachlor. $\mathrm{b}$ Not given. c Standard error about the mean. d GC-MS used for confirmation of positive samples. e Recovery refers only to the absolute recovery from extraction or isolation of the analyte. $f$ Unable to obtain full article. Details taken from abstract. Missing details may be available in full article.

Table 2. Methods for analysis of organochlorine pesticides in human matrices 


\section{Conclusion}

In this chapter, we present a review of existing analytical methodology for the biological and environmental monitoring of exposure to pesticides has been presented. A critical assessment of the existing methodology has been done and other areas which need more research have been identified. An effort has been made to use to measure toxicants. There are many detectors which are equipped with Gas Chromatography like Mass, electron capture detector, flame ionization detector, phosphorous nitrogen detector etc. But, in one modern context the mass detector is the best detector which is very useful for confirmation and quantification of all types of compounds. The electron capture detector is only suitable for quantification of organo-chlorine compounds but it is not confirmatory technique. The nitrogen phosphorous detector is suitable for quantification of nitrogen and phosphorous compounds. Other types of detectors except mass detector are not suitable as confirmatory technique.

\section{References}

A.R., Najam, M.P., Korver, C.C., Williams, V.W., Burse, \& L.L., Needham, (1999). Analysis of mixture of polychlorinated biphenyl and chlorinated pesticides in human serum by column fraction and dual-column capillary gas chromatography with electron capture detection. J. AOAC Int. 82, 177-185.

Abdulrahman, R. B. (2001). Distribution of VOC in ambient air of Tehran, Arch Env Health, $56,380-383$,

Angerer, J., Heinrich, R., \& Laudehr, H., (1981). Occupational exposure to hexachlorocyclohexane. V. Gas chromatographic determination of monohydroxychlorobenzenes (chlorophenols) in urine. Int Arch Occup Environ Health. 48(4), 319-24

Arrebola, F.J., Martinez Vidal, J.L., \& Fernandez-Gutierrez , A., (1999). Excretion study of endosulfan in urine of a pest control operator. Toxicology Letters, 107, 15-20.

Ballschmiter, R., Bacher, A., Mennel, R.C., Fischer, U., Riehle, Swerev, M., (1992). The determination of chlorinated biphenyls, chlorinated dibenzodioxins and chlorinated dibenzofurans by GC-MS. J high Resolution chromatography 15, 260 270. Barcelona. Hum Toxicol 6, 397-400

Barr, D. B., Barr, J. R., Maggio, V. L., Whitehead, R. D., Jr., Sadowski, M. A., Whyatt, R., et al. (2002). A multi-analyte method for the quantification of contemporary pesticides in human serum and plasma using high-resolution mass spectrometry. Journal of Chromatography B, 778, 99-111.

Bichon, E., Richard, C.A., \& Le Bizec, B., (2008). Development and validation of a method for fipronil residue determination in ovine plasma using 96-well plate solid-phase extraction and gas chromatography-tandem mass spectrometry, J Chromatogr A. 2008 1201(1), 91-9.

Bristol, D.W., Crist, H.L., Lewis, R.G., MacLeod, K.E., Sovocool, G.W., (1982). Chemical analysis of human blood for assessment of environmental exposure to semivolatile organochlorine chemical contaminants, J Anal Toxicol. 6(6), 269-75.

Brock, J.W., Burse, V.W., Ashley, D.L., Najam, A.R., Green, V.E., Korver, M.P., Powell, M.K., Hodge, C.C., \& Needham, L. L., (1996). An improved analysis for chlorinated 
pesticides and polychlorinated biphenyls (PCBs) in human and bovine sera using solid-phase extraction. J Anal Toxicol 20, 528-536.

Burse, V.W., Head, S.L., Korver, M.P., McClure, P.C., Donahue, J.F., \& Needham, L.L., (1990). Determination of selected organochlorine pesticides and polychlorinated biphenyls in human serum, J Anal Toxicol. 1990 May-Jun;14(3):137-42

C. Mardones, A., Rios, M., \& Valcarcel, (1999). Determination of chlorophenols in human urine based on the integration of on-line automated clean-up and preconcentration unit with micellar electrokinetic chromatography, Electrophoresis, 20, 2922-2929.

Camino-Sánchez, F.J., Zafra-Gómez, A., Oliver-Rodríguez, B., Ballesteros, O., Navalón, A., Crovetto, G., Vílchez, J.L., (2010) UNE-EN ISO/IEC 17025:2005-accredited method for the determination of pesticide residues in fruit and vegetable samples by LCMS/MS. Food Addit Contam Part A Chem Anal Control Expo Risk Assess. 27(11), 1532-44

Carmichael, P.L., Jacob, J., Grimmer, G., Phillips, D.H. (1990). Analysis of the PAH content of petrol and diesel engine lubricating oils and determination of DNA adductsin topically treated mice by 32 P-post-labelling, Carcinogenesis, 11, 2025-2032

Chen, Q. Fung, Y., (2010). Capillary electrophoresis with immobilized quantum dot fluorescence detection for rapid determination of organophosphorus pesticides in vegetables. Electrophoresis, 31 (18), 3107-3114.

Chung, S.W., Chan, B.T., (2010). Validation and use of a fast sample preparation method and liquid chromatography-tandem mass spectrometry in analysis of ultra-trace levels of 98 organophosphorus pesticide and carbamate residues in a total diet study involving diversified food types, J Chromatography A, 1217(29), 4815-24.

Dewan, A., Bhatnagar, V. K., Mathur, M. L., Chakma, T., Kashyap, R., Sadhu, G. H., et al. (2004). Repeated episodes of endosulfan poisoning. Journal of Toxicology -Clinical Toxicology, 42, 1-7.

E. V., Minelli \& M. L., Ribeiro, (1996). Quantitative method for the determination of organochlorine pesticides in serum. J. Anal. Toxicol., 20(1), 23-26.

Fischer, R. C., Witlinger, R., Ballschmiter, K., (1992). Retention index based vapour pressure estimation for PCB by GC, Fresenius. J of Analytical Chemistry 342, 421-425

Frenzel, T. Sochor, H., Speer K., \& and Uihlein, M., (2000). Rapid multi-method for verification and determination of toxic pesticides in whole blood by means of capillary GC-MS. J. Anal. Toxicol., 24(5), 365-371.

Frenzel, T., Sochor, H., Speer, K., \& Uihlein, M., (2000) Rapid multi-method for verification and determination of toxic pesticides in whole blood by means of capillary GC-MS. J. Anal. Toxicol., 24(5), 365-371

Gallardo, E., Barroso, M., Margalho, C., Cruz, A., Vieira, D. N., \& López-Rivadulla, M., (2006). Solid-phase microextraction for gas chromatographic/mass spectrometric analysis of dimethoate in human biological samples, Rapid Communications in Mass Spectrometry 20( 5), 865-869.

Gallelli, G., Mangini, S.,\& Gerbino, C.,(1995). Organochlorine residues in humans adipose and hepatic tissues from autopsy sources in northern Italy. J. Toxicol. Environ Health 46, 293-300.

Gomez-Catalan, J. J., To-Figueras, J., Planas, M., Rodamilans, J., Corbella, (1987). 
Guardino, X., Serra, C., Obiols, J., Rosell, M.G., Beren guer, M.J., Lopez, F., \& Brosa, J., (1996). Determination of DDT and related compounds in blood samples from agricultural workers J. Chromatogr. A $719,141-147$.

Heleni, T., Georgios, T., Nikolaos, R., \& Ifigeneia G., (2005). Solid phase microextraction gas chromatographic analysis of organophosphorus pesticides in biological samples, Journal of Chromatography B, 822 (1-2)194-200.

Hill, R.H., Shealy Jr, D.B., Head, S.L., Williams, C.C., Bailey, S.L., Gregg, M., Baker, S.E., \& Needham, L.L., (1995). Determination of Pesticide Metabolites in Human Urine Using an Isotope Dilution Technique and Tandem Mass Spectrometry J. Anal. Toxicol. 19, 323-329.

Hodgson AT. Grimmer JR. Application of multisorbent sampling technique for investigations of volatile organic compounds buildings, In: Design and protocol for monitoring of indoor air-quality. ASTM STP 1002, NL Nagota and JP Harper (Eds.) 1989, 244-256

Holler J.S., Fast, D.M., Hill, R.H., Jr, Cardinali, F.L., Todd, G.D., McCraw, J.M., Bailey, S.L., \& Needham, L.L., (1989). Quantification of selected herbicides and chlorinated phenols in urine by using gas chromatography/mass spectrometry/mass spectrometry. J Anal Toxicol. 13(3),152-7.

John, H., Eddleston, M., Clutton, R.E., Worek, F., \& Thiermann, H., (2010). Simultaneous quantification of the organophosphorus pesticides dimethoate and omethoate in porcine plasma and urine by LC-ESI-MS/MS and flow-injection-ESI-MS/MS, J Chromatogr B Analyt Technol Biomed Life Sci. 878(17-18), 1234-45

Kamel, A., Qian, Y., Kolbe, E., Stafford, C., (2010). Development and validation of a multiresidue method for the determination of neonicotinoid and macrocyclic lactone pesticide residues in milk, fruits, and vegetables by ultra-performance liquid chromatography/MS/MS. J AOAC International, 93(2), 389-99.

Keenan, F., Doug, C., Vegetation clearance study work plan ordinance and explosive. Prepared by US Dept. of the Army Sacrament District Corps of Engineers, 1325, J Street, Sacramento, California 95814-2922. HLLA project no. 46310001131

Kmellár, B., Abrankó, L., Fodor, P., Lehotay, S.J., (2010), Routine approach to qualitatively screening 300 pesticides and quantification of those frequently detected in fruit and vegetables using liquid chromatography tandem mass spectrometry (LC-MS/MS). Food Addit Contam Part A Chem Anal Control Expo Risk Assess. 27(10),1415-30.

Koesukwiwat, U., Lehotay, S.J., Miao, S., Leepipatpiboon, N., (2010) High throughput analysis of 150 pesticides in fruits and vegetables using QuEChERS and lowpressure gas chromatography-time-of-flight mass spectrometry. J Chromatography A, 1217(43), 6692-703.

Kumari, B., \& Kathpal, T. S. (2009). Monitoring of pesticide residues in vegetarian diet. Environmental Monitoring Assessment, 151, 19-26.

Kumari, B., Madan, V. K., \& Kathpal, T. S. (2006). Monitoring of pesticide residues in fruits. Environmental Monitoring and Assessment, 123, 407-412.

Kumari, B., Madan, V. K., Kumar, R., \& Kathpal, T. S. (2002). Monitoring of seasonal vegetables for pesticide residues. Environmental Monitoring and Assessment, 74, 263-270. 
LeBel G.L., \& Williams, D.T., (1983). Determination of organic phosphate triesters in human adipose tissue. J Assoc Off Anal Chem. 66(3), 691-9

Li, L., Wu, C., Chen, J., Zhang, S., Ye, Y., (2010). Determination of organophosphorus pesticide residues in vegetables by gas chromatography using back-flush technique. Se Pu. July 28 (7), 724-8

Liao, W., Smith, W.D., Chiang, T.C., \& Williams, L.R., (1988). Rapid, low-cost cleanup procedure for determination of semi-volatile organic compounds in human and bovine adipose tissues , J Assoc Off Anal Chem.71(4), 742-7

Lin, X., Chen, X., Huo, X., Yu, Z., Bi, K., Li, Q., (2010). Dispersive liquid-liquid microextraction coupled with high-performance liquid chromatography-diode array detection for the determination of $\mathrm{N}$-methyl carbamate pesticides in vegetables. journal of Separation Science. PMID: 21137098

Lino, C.M., Azzolini, C.B., Nunes, D.S., Silva, J.M., \& da Silveira, M.I., (1998). Methods for the determination of organochlorine pesticide residues in human serum J. Chromatogr. B $716,147-152$.

Luo, X.W., Foo, S.C., \& Ong, H.Y., (1997). Serum DDT and DDE levels in Singapore general population Sci. Total Environ. $208,97-104$.

Martínez Vidal, J.L., Arrebola, F.J., Fernández-Gutiérrez, A., \& Rams, M.A., (1998). Determination of endosulfan and its metabolites in human urine using gas chromatography-tandem mass spectrometry, J Chromatogr B Biomed Sci Appl. 719(1-2), 71-8.

Martinez, J. L. V., Arrebola, F. J., Garrido, A. F., Martinez, J. F., \& Mateu-Sanchez, M. (2004). Validation of a gas chromatographic-tandem mass spectrometric method for analysis of pesticide residues in six food commodities. Selection of a reference matrix for calibration. Chromatographia, 59(5-6), 321-327.

Miller, K. D., \& Milne, P. (2008). Determination of low-level pesticides residues (0.5 lg/L) in soft drinks and sport drinks by gas chromatography with mass spectrometry: Collaborative study. Journal of AOAC International, 91(1), 202-236.

Najam, A.R., Korver, M.P., Williams, C.C., Burse, V.W., \& Needham, L L., (1999) Analysis of a mixture of polychlorinated biphenyls and chlorinated pesticides in human serum by column fractionation and dual-column capillary gas chromatography with electron capture detection. J. AOAC Int. 82, 177-185.

Nigg, H. N., Stamper, J. H., Deshmukh S. N., \& Queen, R. M., (1991). 4,4'-Dichlorobenzilic acid urinary excretion by dicofol pesticide applicators, Chemosphere. 22, (3-4) , 365-373.

Norén, K., Lundén, A., Pettersson, E., \& Bergman, A., ( 1996). Methylsulfonyl metabolites of PCBs and DDE in human milk in Sweden, 1972-1992. Environ Health Perspect. 104(7), 766-772

Osman, K.A., Al-Humaid, A. M., Al-Rehiayani, S.M., Al-Redhaiman, K.N., (2010). Monitoring of pesticide residues in vegetables marketed in Al-Qassim region, Saudi Arabia. Ecotoxicol Environ Saf. 73(6), 1433-9.

Paula, P., Helena, T., Fernando, C., João, P., Paula ,V., Monsanto, E., Marques, P., \& Duarte N. V., (2005). Two fatal intoxication cases with imidacloprid: LC/MS analysis, Forensic Science International. Volume 153(1) ,75-80 
Pauwels, A., Wells, D., Covaci, A., \& Schepens, P.J.C. (1999). Improved sample preparation method for selected persistent organochlorine pollutants in human serum using solidphase disk extraction with gas chromatographic analysis. J Chromatogr B 723:117-125.

Paya, P., Anastassiades, M., Mack, D., Sigalova, I., Tasdelen, B., Oliva, J., et al. (2007). Analysis of pesticide residues using the Quick Easy Cheap Effective Rugged and Safe (QuEChERS) pesticide multiresidue method in combination with gas and liquid chromatography and tandem mass spectrometric detection. Analytical Bioanalytical Chemistry, 389, 1697-1714.

Pentachlorophenol and hexachlorobenzene in serum and urine of the population of Prapamontol T., \& Stevenson, D., (1991). Rapid method for the determination of organochlorine pesticides in milk. J Chromatogr 552:249-257.

Quach, D.T.I.,. Ciszkouzski, N. A. P., Fienlayson, J., Barbara, A., (1998). New GC-MS experiment for the undergraduate instrumental laboratory in environmental chemistry: methyl -t-butyl ether and benzene in gasoline. J Chem Educ 75. 595-599.

Reidel, K. (1996). Determination of benzene and alkylated biomass in ambient and exhaled air by microwave desorption coupled with GC-MS. J of Chromatography A 719, 383-389.

Robert H. TPH measurements; the advantage of using GC-MS. 1995: PhD. Dissrtation. ENTRIX INC JHON MAC MURPHY ZYMAX ENVIR TECHNOLOGY INC.

Rohrig, L., Meisch, H.U., \& Fresenius, J., (2000). Application of solid phase micro extraction for the rapid analysis of chlorinated organics in breast milk Anal. Chem. 366 , 106111

Saady J.J., \& Poklis A., (1990). Determination of chlorinated hydrocarbon pesticides by solidphase extraction and capillary GC with electron capture detection J Anal Toxicol. 1990 Sep-Oct;14(5):301-4

Saito, T., Morita, S., Motojyuku, M., Akieda, K., Otsuka, H., Yamamoto, I., \& Inokuchi, S., (2008). Determination of metaldehyde in human serum by headspace solid-phase microextraction and gas chromatography-mass spectrometry, J Chromatogr B Analyt Technol Biomed Life Sci. 875(2), 573-6.

Sinha SN. Kulkarni, P.K. Desai, N. M., Shah, S. H., Patel, G.M., Mansuri, M.M., Parih, D. J., Saiyed, H.N. (2005). Gas chromatographic-mass spectroscopic determination of benzene in Indoor air during the use of biomass fuels in cooking time, J of chromatography A 315-319.

Sinha SN. Kulkarni, P.K. Shah, S. H., Desai, N. M., Patel, G.M., Mansuri, M.M., Saiyed, H.N. (2006). Environmental monitoring of benzene and toluene produced in indoor air due to combustion of solid biomass fuels, Science of the Total Environment 357, 280-287.

Sinha, S. N. (2010). Effect of dissociation energy: Signal to noise ratio on ion formation and sensitivity of analytical method for quantification and confirmation of triazofos in blood samples using gas chromatography-mass spectrometer (GC-MS/MS). International Journal of Mass Spectrometry, 296, 47-52.

Sinha, S. N., Bhatnagar, V.K., Doctor, P., Toteja, G.S., Agnihotri, N.P., Kalra R.L., A novel method for pesticide analysis in refined sugar samples using a gas 
chromatography-mass spectrometer (GC-MS/MS) and simple solvent extraction method, Food Chemistry 126 (2011) 379-386

Sinha, S. N., Pal, R., Dewan, A., Mansuri, M. M., \& Saiyed, H. N. (2006). Effect of dissociation energy on ion formation and sensitivity of an analytical method for determination of chlorpyrifos in human blood, using gas chromatography-masss pectrometer (GC-MS in MS/MS). International Journal of Mass Spectrometry, 253, 48-57.

Sinha, S. N., Patel, T. S., Desai, N. M., Mansuri, M. M., Dewan, A., \& Saiyed, H. N. (2004). GC-MS study of endosulfan in biological samples. Asian Journal of Chemistry, 16(3-4), 1685-1690.

Sinha, S. N., Zadi, S. S. (2008). Gas Chromatography-Mass spectral analysis of paint thinner, Asian Journal of Chemistry 20(8), 6365-6368.

Srivastava, A.K., Trivedi, P., Srivastava, M.K., Lohani, M., \& Srivastava, L.P. (2011). Monitoring of pesticide residues in market basket samples of vegetable from Lucknow City, India: QuEChERS method. Environmental Monitoring and Assessment, 176(1-4, 465-472.

Star J. M., Rone, J.R., Metnacche, M.G., Henderson, R. F. (2000). Development of methods for analysis of biomarkers of Benzene exposure using GC/MS and MALDI. The Toxicologist. Presented at the Annual meeting of the society of Toxicology, Philadelphia, 54, 310.

Strassman S.C., \& Kutz, F.W., (1977). InseAicide residues in human milk from Arkansas and Mississippi,1 973-1974.Pestic Monit J , 10(4),1 30-133.

Tessari, J.D., \& Savage, E.P., (1980). Gas-liquid chromatographic determination of organochlorine pesticides and polychlorinated biphenyls in human milk. J Assoc Off Anal Chem. 1980 Jul;63(4):736-41.

U. S., Gill, H. M., Schwartz, B. Wheatley, (1996). Development of a method for the analysis of PCB congeners and organochlorine pesticides in blood/serum. Chemosphere Volume: 32 (6), 1055-1076.

Waliszewski, S.M., \& Szymczynski, G.A., (1982). Simple, low-cost method for determination of selected chlorinated pesticides in fat samples J. Assoc. Off. Anal. Chem. 65, 677-9.

Ward, E.M., Schulte, P., Grajewski, B., Andersen, A., Patterson Jr., D.G., Turner, W., Jellum, E., Deddens, J.A., Fried- land, J., Roeleveld, N., Waters, M., Butler, M.A., DiPietro, E., \& Needham, L.L., (2000). Serum organochlorine levels and breast cancer: a nested case-control study of Norwegian women. Cancer Epidemiol. Biomarkers Prev. 9, 1357-1367.

Ward, E.M., Schulte, P., Grajewski, B., Andersen, A., Patterson, D.G., Jr, Turner, W., Jellum, E., Deddens, J.A., Friedland, J., Roeleveld, N., Waters, M., Butler, M.A., DiPietro, E., \& Needham, L.L., (2000). Serum organochlorine levels and breast cancer: a nested case-control study of Norwegian women. Cancer Epidemiol Biomarkers Prev. 9(12), 1357-67.

Zhou, Y., Jiang, Q., Peng, Q., Xuan, D., \& Qu, W., (2007). Development of a solid phase microextraction-gas chromatography-mass spectrometry method for the determination of pentachlorophenol in human plasma using experimental design. Chemosphere. 2007 70(2), 256-62. 
Zlatković, M., Jovanović, M., Djordjević, D., \& Vucinić, S., (2010). Rapid simultaneous determination of organophosphorus pesticides in human serum and urine by liquid chromatography-mass spectrometry, Vojnosanit Pregl. 67(9),717-22. 


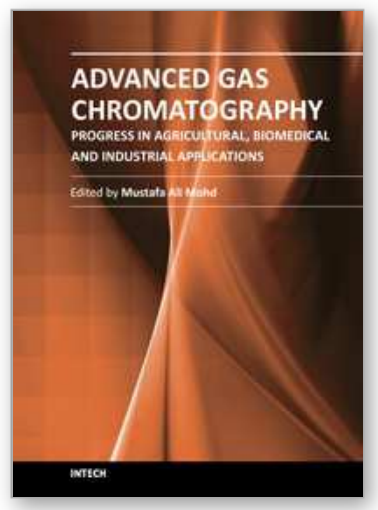

\author{
Advanced Gas Chromatography - Progress in Agricultural, \\ Biomedical and Industrial Applications \\ Edited by Dr. Mustafa Ali Mohd
}

ISBN 978-953-51-0298-4

Hard cover, 460 pages

Publisher InTech

Published online 21, March, 2012

Published in print edition March, 2012

Progress in agricultural, biomedical and industrial applications' is a compilation of recent advances and developments in gas chromatography and its applications. The chapters cover various aspects of applications ranging from basic biological, biomedical applications to industrial applications. Book chapters analyze new developments in chromatographic columns, microextraction techniques, derivatisation techniques and pyrolysis techniques. The book also includes several aspects of basic chromatography techniques and is suitable for both young and advanced chromatographers. It includes some new developments in chromatography such as multidimensional chromatography, inverse chromatography and some discussions on two-dimensional chromatography. The topics covered include analysis of volatiles, toxicants, indoor air, petroleum hydrocarbons, organometallic compounds and natural products. The chapters were written by experts from various fields and clearly assisted by simple diagrams and tables. This book is highly recommended for chemists as well as non-chemists working in gas chromatography.

\title{
How to reference
}

In order to correctly reference this scholarly work, feel free to copy and paste the following:

Sukesh Narayan Sinha and V. K. Bhatnagar (2012). Analysis of Toxicants by Gas Chromatography, Advanced Gas Chromatography - Progress in Agricultural, Biomedical and Industrial Applications, Dr. Mustafa Ali Mohd (Ed.), ISBN: 978-953-51-0298-4, InTech, Available from: http://www.intechopen.com/books/advanced-gaschromatography-progress-in-agricultural-biomedical-and-industrial-applications/analysis-of-toxicants-by-gaschromatography

\section{INTECH}

open science | open minds

\section{InTech Europe}

University Campus STeP Ri

Slavka Krautzeka 83/A

51000 Rijeka, Croatia

Phone: +385 (51) 770447

Fax: +385 (51) 686166

www.intechopen.com

\section{InTech China}

Unit 405, Office Block, Hotel Equatorial Shanghai

No.65, Yan An Road (West), Shanghai, 200040, China 中国上海市延安西路65号上海国际贵都大饭店办公楼405单元

Phone: +86-21-62489820

Fax: +86-21-62489821 
(C) 2012 The Author(s). Licensee IntechOpen. This is an open access article distributed under the terms of the Creative Commons Attribution 3.0 License, which permits unrestricted use, distribution, and reproduction in any medium, provided the original work is properly cited. 